\title{
Distribution and function of epistomatal mucilage plugs
}

\author{
M. Westhoff • D. Zimmermann • G. Zimmermann • \\ P. Gessner • L. H. Wegner • F.-W. Bentrup • \\ U. Zimmermann
}

Received: 22 October 2008 / Accepted: 17 December 2008 / Published online: 15 January 2009

(C) The Author(s) 2009. This article is published with open access at Springerlink.com

\begin{abstract}
Investigation of 67 gymnosperm and angiosperm species belonging to 25 orders shows that epistomatal mucilage plugs are a widespread phenomenon. Measurements of the leaf water status by using the leaf patch clamp pressure technique suggest that the mucilage plugs are involved in moisture uptake and buffering leaf cells against complete turgor pressure loss at low humidity.
\end{abstract}

Keywords Mucilage - Epistomatal plugs · Leaf water status · Turgor pressure - Water ascent $\cdot$ Patch clamp pressure

M. Westhoff · G. Zimmermann · P. Gessner •

U. Zimmermann $(\bowtie)$

Lehrstuhl für Biotechnologie, Biozentrum,

Universität Würzburg,

Am Hubland,

97074 Würzburg, Germany

e-mail: zimmermann@biozentrum.uni-wuerzburg.de

D. Zimmermann

Abteilung für Biophysikalische Chemie,

Max-Planck-Institut für Biophysik,

Max-von-Laue-Str. 3,

60438 Frankfurt a. M., Germany

L. H. Wegner

Plant Bioelectrics Group, Karlsruhe Institute of Technology,

76131 Karlsruhe, Germany

F.-W. Bentrup

Abteilung für Pflanzenphysiologie, Universität Salzburg,

Hellbrunnerstr. 34,

5020 Salzburg, Austria

\section{Introduction}

Acid mucopolysaccharides have been detected in the xylem vessels of higher plant species, particularly in trees (Zimmermann et al. 2004). Drought and salinity stress enforce xylem-bound mucilage formation (Zimmermann et al. 1994, 2002; Zimmermann et al. 2007a). Xylem-bound mucilage is most probably involved in water lifting against gravity (Plumb and Bridgman 1972; Pollack 2001; Zimmermann et al. 2004; Yeo and Flowers 2007). Recent studies have shown (Zimmermann et al. 2007a) that transpirational water loss and moisture uptake from the atmosphere are also modulated by mucilage. In some species (e.g. Eucryphia cordifolia and Astronium fraxinifolium) the leaf surface is covered by a layer of acid mucopolysaccharides. Epistomatal cavities filled with mucilage are chararacteristic for the leaves of the salt-tolerant trees A. fraxinifolium and Bulnesia sarmientoi as well as for the salt-intolerant trees Populus nigra, Eucalyptus pilularis and Nothofagus dombeyi. Zimmermann et al. (2007a) gave a large body of evidence that epistomatal mucilage plugs and acid mucilage layers are not only able to buffer changes in leaf water status when transpiration is high, but also facilitate moisture uptake from the atmosphere (including fog, rain, ascending transpirational water from lower leaves and evaporation from the soil). Via foliar moisture uptake apical leaves of tall trees are immediately supplied with water, whereas water uptake from the roots needs many days (up to 4 weeks; Woodward 2004).

In this short communication we will show that epistomatal mucilage plugs (and mucilage surface layers) are a widespread phenomenon found in higher plants and trees growing on fogladen coasts, in subtropical and tropical rainforests, but also in temperate zones upon exposure to drought. 


\section{Materials and methods}

\section{Plant material}

Leaves of tropical, subtropical and deciduous shrubs and trees were collected at their common habitat in Central Europe, Chile/Argentina, Crete, South-East Asia, Australia and New Zealand, respectively. Immediately after collection leaves were incubated in an aqueous $0.5 \%$ alcian blue solution ( $\mathrm{pH} 3$ ) for $24 \mathrm{~h}$. The leaves were then rinsed very carefully with distilled water or with $3 \%$ acetic acid solution to remove excess alcian blue. Cross-sections and surface sections of the stained leaf pieces were made by hand. Sections were inspected by using a transmitted-light microscope (BX51; Olympus, Hamburg, Germany) equipped with a digital camera or a 3-D digital incidentlight microscope (VHX-100; Keyence, Osaka, Japan).

\section{Leaf water status}

Leaf water status (i.e. turgor pressure) was measured online using the non-invasive leaf patch clamp pressure probe. The principle of the probe and the theoretical background of the parameter measured by the probe are described in details elsewhere (Zimmermann et al. 2008; Westhoff et al. 2009). Briefly, the leaf is positioned in the space between the two planar circular pads of the probe. A miniaturised, temperature-independent pressure sensor chip is integrated in one of the pads. A constantly kept, external clamp pressure (up to $250 \mathrm{kPa}$ ) is applied by a spring (Zimmermann et al. 2008) or a magnet (Westhoff et al. 2008) to the clamped leaf patch. Physics shows that the output pressure $P_{P}$ measured by the sensor is dictated by the pressure transfer function of the clamped leaf patch. The transfer function is related to the compressibility of the leaf patch and therefore varies exclusively with cell turgescence for a leaf of a given species. At high turgor pressure the transfer function assumes values close to zero, i.e. $P_{p}$ is small. At very low turgor pressure the transfer function assumes values close to unity, i.e. the applied pressure is transferred to the sensor at most and $P_{p}$ assumes a maximum value. In other words, $P_{p}$ measured by the pressure sensor is inversely correlated to turgor pressure. This was shown by calibration of the patch clamp pressure probe against the cell turgor pressure probe (Zimmermann et al. 2008).

\section{Results and discussion}

Typical examples of epistomatal mucilage plugs are given in Fig. 1a-i. Leaves of 57 angiosperm and 10 gymnosperm species were investigated (Fig. 2). 81\% of the species contained epistomatal mucilage plugs. The angiosperms belonged to 23 orders, the gymnosperms to the orders Pinales and Taxales. Leaves of species belonging to the orders Euphorbiales, Clusiales, Ericales, Myristicales, Oleales and Taxales showed no epistomatal mucilage plugs, whereas species belonging to the orders Apiales, Burserales, Caryophyllales, Fabales, Fagales, Hamamelidales, Oxalidales, Pinales, Polygonales, Proteales, Rosales, Lamiales, Urticales, Salicales, Scrophulariales, Vitales, Winterales, Zygophyllales exhibited epistomatal mucilage plugs and/or acid mucilage layers (Fig. 2). Species of the orders Fabales, Apiales, Myrtales and Salicales did not always contain mucilage plugs ( 1 out of 4 species, 1 out of 3 species, 2 out of 12 species and 1 out of 4 species, respectively). All the investigated species of the other orders showed mucilage plugs. Even though the sample size was rather small several interesting conclusions could be drawn from the evaluation of the images of alcian bluestained leaves of the 67 species investigated here and previously (Zimmermann et al. 2007a).

Gymnosperms showed a larger tendency to form plugs than angiosperms. The plug density both on the adaxial and abaxial side of the species of the order Pinales was $72 \% \pm$ $26 \%(n=9)$. Evergreen species showed generally a higher mucilage plug density than deciduous or semi-evergreen species $(56 \% \pm 29 \% ; \mathrm{n}=37$ versus $42 \% \pm 22 \% ; \mathrm{n}=17)$. Examples for high plug density are Bulnesia arborea, Tristania sumatrana (Fig. 1e), Eucalyptus pilularis and Podocarpus nubigenus. The plug density of leaves of trees of tropical broadleaf rainforest and monsoon forest as well as subtropical broadleaf and needleleaf forest was frequently very high (average plug density: 66\% $\pm 29 \% ; n=37$ ). More than half of these trees (c. 62\%) showed an epistomatal mucilage plug density of $60-100 \%$ of the stomata (e.g. Astronium fraxinifolium, Tibouchina mutabilis and Veronica lasiocarpa). Plug densities of this magnitude were only found in about one third of evergreen broadleaf, deciduous trees and shrubs, and broadleaf deciduous woodland of the temperate zones and the Mediterranean region (e.g. Eucalyptus globulus, Ficus carica and Quercus coccifera). The alcian blue precipitates of the leaves of these trees were also not as concise as in the case of leaves of trees growing in the tropical and subtropical forests, but still clearly identifiable. Extended studies on Populus nigra in Germany indicated a seasonal dependency of the plug density which resulted most likely from drought. Between May and June, 2006, no plugs could be detected on $25 \mathrm{~m}$ tall trees growing at the river Tauber, Germany, and on a hill c. $1 \mathrm{~km}$ away $\left(18 \mathrm{May}, \mathrm{T}=11-15^{\circ} \mathrm{C}, \mathrm{R} . \mathrm{H} .=85-95 \%\right.$ and 6 June, $\mathrm{T}=10-14^{\circ} \mathrm{C}, \mathrm{R} . \mathrm{H} .=68-98 \%$ ). Plugs were first found on 20 June 2006 (plug density c. 5 - 10\%). The number increased during the following two very dry and hot months (18 July, tree at the river Tauber, 40 - 50\% plug density, $\mathrm{T}=25-32^{\circ} \mathrm{C}$ and R.H. $=35-55 \%$; tree on the near- 
Fig. 1 Evidence for epistomatal mucilage plugs extending into the substomatal cavity (a-i) and effect of mucilage plugs on the leaf water status ( $\mathrm{j}$ and $\mathrm{k}$ ).

Mucilage-containing plugs in (ai) were verified by exposure of leaves or leaf pieces to a $0.5 \%$ alcian blue solution for $24 \mathrm{~h}$. (a), (b) and (c) microscopical crosssections of plugged stomata of Drimys winteri, Agathis australis (trivial name Kauri-tree; gymnosperm) and Vitis vinifera; (d), (e) and (f) top views on the abaxial leaf surface of $A$. australis, Tristania sumatrana (angiosperm) and Nothofagus dombeyi (angiosperm); (g), (h) and (i) 3-D reconstructions of a stomata on the abaxial leaf surface of Ficus superba (angiosperm), Podocarpus totara (gymnosperm) and Metrosideros excelsa (angiosperm) obtained with a 3-D digital incident-light microscope; (j) and (k) plots of patch output pressure $P_{p}$ values against the corresponding R.H. values recorded during the morning (filled circles) and afternoon hours (open circles) on leaves of a well-watered, no plugs containing (j) and a drought-exposed, plug-containing (k) Vitis vinifera grapevine in neighbouring vineyards in Israel. Note that in contrast to $(\mathrm{j})$ $P_{p}$ in (k) reached a plateau value below about $50 \%$ R.H. if epistomatal mucilage plugs were present; the sigmoid curve was approximated by the least square method $\left(r^{2}=0.97\right)$. As indicated, the kinetics of refilling during the afternoon varied generally considerably, presumably due to variability of water supply. p: epistomatal plug; g: guard cell
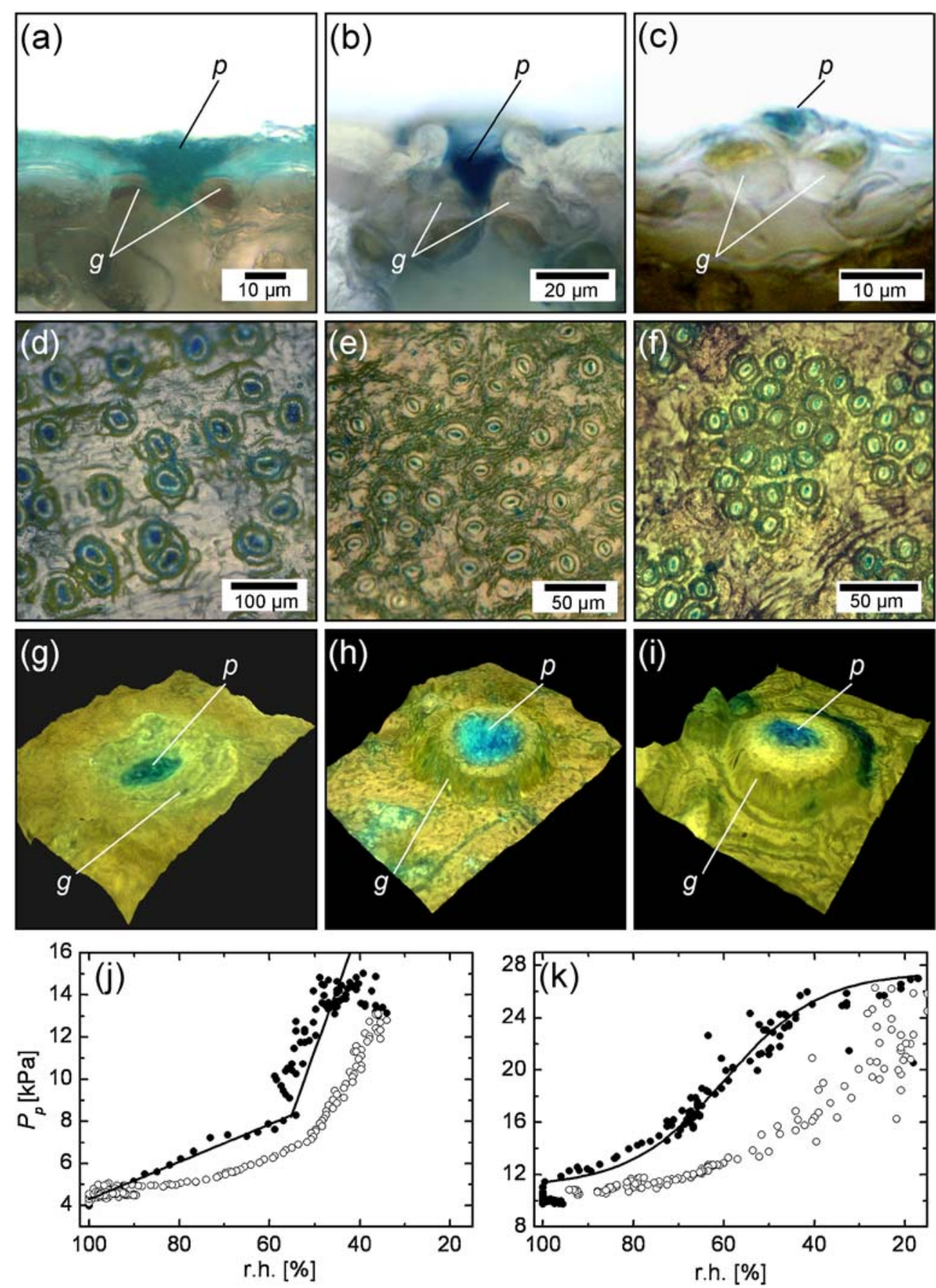

by hill, $60-70 \%$ plug density, $\mathrm{T}=32-35^{\circ} \mathrm{C}$, R.H. $=21-$ $29 \%$ ). At the end of August the tree at the river Tauber also exhibited a similar plug density as the tree on the hill. The stomata density of the trees at both locations was with $75 \pm$ 24 stomata per $\mathrm{mm}^{2}(\mathrm{n}=60)$ comparable. A dependency of plug density on water supply was also found for Vitis vinifera (Fig. 1c) and Eucalyptus pilularis. Grapevines watered daily in Kiryat Gat, Israel exhibited no or few plugs whereas non-irrigated or only weekly irrigated grapevines (Würzburg, Germany and Gedera, Israel, respectively) exhibited high plug densities (June 2007, Kyriat
Gat, less than $5 \% \pm 1 \%(\mathrm{n}=173)$ plug density, $\mathrm{T}=15-40^{\circ} \mathrm{C}$ and R.H. $=21-100 \%$; June 2007, Gedera, $28 \% \pm 15 \%(\mathrm{n}=$ 87) plug density, $\mathrm{T}=13-40^{\circ} \mathrm{C}$ and R.H. $=28-100 \%$; August 2007, Würzburg, $65 \% \pm 20 \%(\mathrm{n}=70)$ plug density, $\mathrm{T}=6-35^{\circ} \mathrm{C}$ and R.H. $=8-100 \%$ ). Similarly, a well-watered E. pilularis tree growing in a garden in New South Wales, Australia, showed only a few epistomatal mucilage plugs (plug density $50 \%$ on the abaxial side; the adaxial side did not contain stomata) compared to the high plug density found for trees of similar height growing at the edge of a relatively dry forest (depending on the age the plug density 


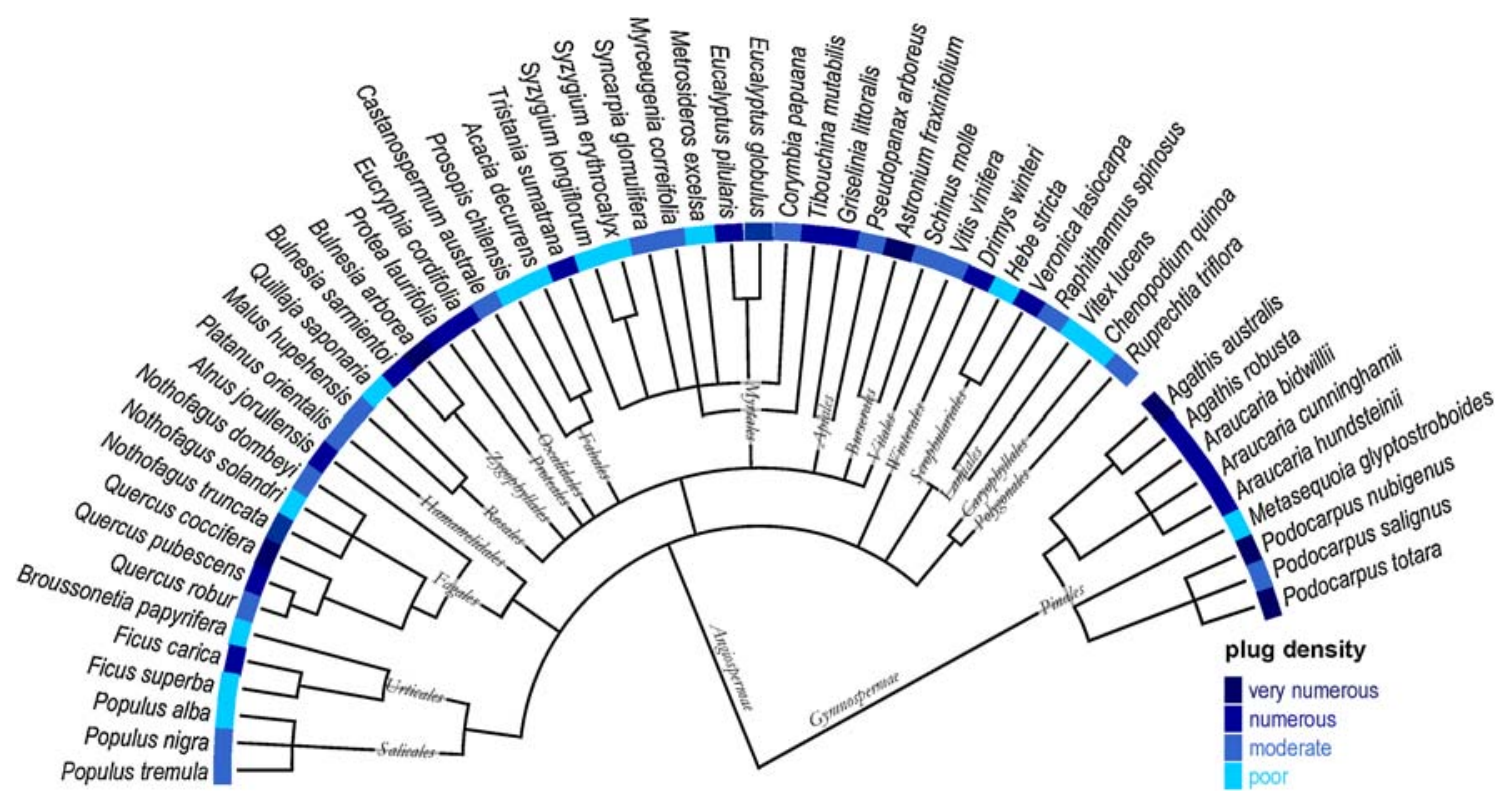

Fig. 2 Phylogenetic tree of the 67 investigated plant species and their tendency to generate epistomatal mucilage plugs (incl. mucilage layer). Plug density: up to $30 \%$ : poor; $30-60 \%$ : moderate, $60-90 \%$ : numerous and $90-100 \%$ very numerous

reached up to $100 \%$ on the abaxial and c. $15 \%$ on the adaxial side). Trees which could reach heights of $50 \mathrm{~m}$ and more (e.g. E. pilularis and Agathis australis (Figs. 1b and d)) showed an increase of plug density with height suggesting that their formation is enhanced once water supply from the roots is limited (E. pilularis, plug density $80-100 \%$ at $55 \mathrm{~m}$ height, 9 March $2006, \mathrm{~T}=18-28^{\circ} \mathrm{C}$, R. $\mathrm{H} .=60-100 \%)$. This is also supported by the finding that the abaxial stomatal cavities of young leaves of $30-60 \mathrm{~m}$ tall $E$. pilularis were less filled with plugs than older ones ( $5 \%$ to $50 \%$ versus $80 \%$ to $100 \%$ ).

An interesting result is also the finding that Podocarpus totara (Fig. 1h) being endemic to New Zealand and Podocarpus nubigenus being endemic to South-Chile had a high capacity for plug formation. Both species are growing in a comparable ecosystem. Two further examples for high plug densities in species belonging to the same genus are Agathis australis (Figs. 1b and d), being endemic to the northern island of New Zealand, and Agathis robusta being endemic to South-East-Queensland, Australia, as well as Nothofagus dombeyi (Fig. 1f) being endemic to South-Chile/ Argentina and Nothofagus truncata being endemic to New Zealand. By contrast, leaves of Griselinia littoralis being endemic to New Zealand exhibited high plug densities, whereas leaves of Griselinia scandens being endemic to South-Chile showed no plugs even though they grow in a comparable biome. These findings obviously demonstrate that the capability for epistomatal mucilage and mucilage layer formation not always continued after the fragmentation of the supercontinent Pangaea into the present continents during the Triassic period (200 million years ago). Reasons for this may be different microclimate conditions.
In the light of the above results we can conclude that epistomatal mucilage plugs (and layers) are a widespread phenomenon. Water uptake and binding of acid mucopolysaccharides are extremely high, in particular in the presence of di-(multi-)valent cations (Morse 1990; McCully and Boyer 1977; Esch et al. 1999; Zimmermann et al. 2007b). This suggests that epistomatal mucilage plugs (and layers) are involved in moisture uptake and particularly in buffering the leaves against rapid and excessive turgor pressure loss at low relative humidity. Support for this assumption is given by leaf patch clamp pressure measurements. Plots of the output pressure $P_{p}$ values measured on non-irrigated (mucilage plug-rich) and irrigated (mucilage plug-free) Vitis vinifera grapevines against the ambient $\mathrm{R}$. H. show large differences in curve shape. As indicated in Fig. $1 \mathrm{j}$ and $\mathrm{k}$ the $P_{p}$ values increased (i.e. turgor pressure values decrease) with decreasing R.H. However, whereas the $P_{p}$ values of the non-irrigated grapevines assumed a plateau value (corresponding to a constant turgor pressure) below about $50 \%$ R.H. (sigmoid curve shape, found in $83 \%$ of 30 R.H. plots), the $P_{p}$ values of the well-watered grapevines increased dramatically when R.H. dropped further below $45-55 \%$ around noon (found in $90 \%$ of 31 R.H. plots). A sigmoid-shaped dependency of the $P_{p}$ - R.H. relationship was also found for mucilage plug-rich leaves of E. pilularis using both the leaf patch clamp pressure probe (data not shown) and the Scholander pressure bomb (see Fig. 5 in Zimmermann et al. 2007a). Both techniques measure changes in turgor pressure in the low pressure range as shown recently (Westhoff et al. 2009).

Further work is certainly necessary to unravel the role of epistomatal mucilage plugs in more detail, but the results 
presented here demonstrate that the water binding capacity of acid mucopolysaccharides has to be taken into account in the discussion about water ascent and leaf water supply.

Acknowledgments We are very grateful to Stefanie Nieft for performance of the microscopical cross-sections.

Open Access This article is distributed under the terms of the Creative Commons Attribution Noncommercial License which permits any noncommercial use, distribution, and reproduction in any medium, provided the original author(s) and source are credited.

\section{References}

Esch M, Sukhorukov VL, Kürschner M, Zimmermann U (1999) Dielectric properties of alginate beads and bound water relaxation studied by electrorotation. Biopolymers 50:227-237 doi:10.1002/ (SICI)1097-0282(199909)50:3<227::AID-BIP1>3.0.CO;2-Y

McCully ME, Boyer JS (1997) The expansion of maize root-cap mucilage during hydration. 3. Changes in water potential and water content. Physiol Plant 99:169-177 doi:10.1111/j.13993054.1997.tb03445.x

Morse SR (1990) Water balance in Hermizonia luzulifolia: the role of extracellular polysaccharides. Plant Cell Environ 13:39-48 doi:10.1111/j.1365-3040.1990.tb01297.x

Plumb RC, Bridgman WB (1972) Ascent of sap in trees. Science 176:1129-1131 doi:10.1126/science.176.4039.1129

Pollack GH (2001) Cells, gels and the engines of life. Ebner and Sons, Seattle, WA, USA, pp 270-272

Westhoff M, Reuss R, Zimmermann D, Netzer Y, Gessner A, Geßner P, Zimmermann G, Wegner LH, Bamberg E, Schwartz A,
Zimmermann U (2009) A non-invasive probe for onlinemonitoring of turgor pressure changes under field conditions. Plant Biol (in press)

Woodward I (2004) Tall storeys. Nature 428:807-808 doi:10.1038/ $428807 \mathrm{a}$

Yeo AR, Flowers TJ (2007) Plant Solute Transport. John Wiley \& Sons, New York

Zimmermann U, Zhu JJ, Meinzer F, Goldstein G, Schneider H, Zimmermann G, Benkert R, Thürmer F, Melcher P, Webb D, Haase A (1994) High molecular weight organic compounds in the xylem sap of mangroves: Implications for long-distance water transport. Bot Acta 107:218-229

Zimmermann U, Wagner H-J, Heidecker M, Mimietz S, Schneider H, Szimtenings M, Haase A, Mitlöhner R, Kruck W, Hoffmann R, König W (2002) Implications of mucilage on pressure bomb measurements and water lifting in trees rooting in high-salinity water. Trees (Berl) 16:100-111 doi:10.1007/s00468-001-0135-5

Zimmermann U, Schneider H, Wegner LH, Haase A (2004) Water ascent in tall trees: does evolution of land plants rely on a highly metastable state. New Phytol 162:575-615 Tansley Review doi:10.1111/j.1469-8137.2004.01083.x

Zimmermann D, Westhoff M, Zimmermann G, Geßner P, Gessner A, Wegner LH, Rokitta M, Ache P, Schneider H, Vásquez JA, Kruck W, Shirley S, Jakob P, Hedrich R, Bentrup F-W, Bamberg E, Zimmermann U (2007a) Foliar water supply of tall trees: evidence for mucilage-facilitated moisture uptake from the atmosphere and the impact on pressure bomb measurements. Protoplasma 232:11-34 doi:10.1007/s00709-007-0279-2

Zimmermann H, Shirley SG, Zimmermann U (2007b) Alginate-based encapsulation of cells: Past, present, and future. Curr Diab Rep 7:1534-4827 doi:10.1007/s11892-007-0051-1

Zimmermann D, Reuss R, Westhoff M, Geßner P, Bauer W, Bamberg E, Bentrup F-W, Zimmermann U (2008) A novel, non-invasive, online-monitoring, versatile and easy plant-based probe for measuring leaf water status. J Exp Bot 59:3157-3167 doi:10.1093/jxb/ern171 